\section{US government rejects plea for nuclear waste inquiry}

\begin{abstract}
Washington. The US Department of Energy (DoE) has acknowledged that it will not be able to meet its obligation to accept nuclear waste from power stations in 1998, and has invited the operators of such stations to discuss alternatives - such as compensating them for storing waste locally instead.

The department's action, announced last week in the Federal Register, has been seized on by its critics as evidence that the government's nuclear waste policy is in disarray. But Hazel O'Leary, the Secretary of Energy, promptly rejected a call from a broad coalition of environmental groups for a presidential commission to find new approaches to the management of nuclear waste.

Such a commission was proposed two weeks ago in a letter to President Bill Clinton from the Sierra Club,

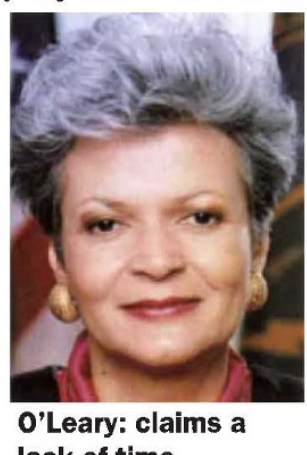
O'Leary: claims a lack of time.
\end{abstract}

Public Citizen and dozens of other environmental groups, and endorsed by 40 senators and congressmen. But O'Leary says that a commission would take 15 months to establish. "I just don't have the time," she adds.

The DoE's notice states its view - which is likely to be challenged in the courts by electricity utilities - that it has no legal obligation to take the waste, because it has no repository. The notice raises the question of whether an interim central store is needed, and of whether the department should release compensation from the \$6 billion nuclear waste fund to help utilities to pay for temporary local storage.

Utilities and other interested parties have four months to respond to the notice. O'Leary is thought to favour subsidizing local storage, leaving the utilities to fight for and build an interim central store if they so choose, and proceeding with the painstaking process of constructing a permanent store at Yucca Mountain, Nevada, for completion by 2010 at the earliest.

A DoE "stakeholders' meeting" on highlevel nuclear waste held in Las Vegas last week was told that the use of standard, multi-purpose canisters would assist the safe storage of waste on local sites until central storage became available at some future date.

But environmentalists say that a commission is needed to establish a national consensus that would lift the issue from its current quagmire of doubt. "We need an independent review because no-one really knows what we're doing," says Martin
Gelfand, research director of a Washingtonbased lobby group, the Safe Energy Communication Council. He professes surprise at DoE's dismissal of the proposal for a commission. "We don't understand why they are so headstrong, because they don't know where they're heading," he says.

Some environmentalists would certainly like the government to procrastinate on nuclear waste management, hoping that the resulting logjam would cripple the nuclear power industry. But they deny that the call for the commission is a stalling tactic.

They say that the long-delayed plans for permanent storage of 70,000 tonnes of highlevel civil waste at Yucca Mountain and military waste at the Waste Isolation Pilot Plant near Carlsbad, New Mexico, will never be realized and should be replaced with a programme determined by a presidential commission via a "public, scientifically-

But with no central storage facility in sight, nuclear power stations face mounting difficulties. "Within four years, 23 units will run out of storage space, and by the year 2010, 73 units will run out," says Phillip Bayne, president of the Nuclear Industry Institute, the main industry lobby group.

In contrast with the emerging pattern in Europe, central storage is the industry's favoured option, probably because local politics in the United States makes local storage highly problematical.

Plans for a Monitored Retrievable Storage facility for interim storage have been pursued by an independent agency, the Office of the Nuclear Waste Negotiator. But negotiations with several Indian tribes to take waste on reservation land proved politically explosive, and Congress has cut off its money from the end of the year.

The first and most organized tribe - the Mescalero Apaches in New Mexico - is now pursuing the idea of a privately built interim store. This week, 33 utilities are expected to agree to proceed with the detailed planning phase of such a store, which would hold 20,000 tonnes of high-level waste and cost a moderate $\$ 150$ million to build. They would then apply for a licence from the Nuclear Regulatory Commission.

This plan will meet fierce opposition from environmentalists, and from politicians such as Senator Jeff Bingaman (Democrat, New Mexico), whose amendment to an appropriations bill last autumn killed off the negotiator's office. If the Mescalero private store dies too, the United States is likely to see little real progress on the high-level waste issue apart from more local storage, and endless scientific reassessment of the Yucca Mountain site.

Colin Macilwain sound process".

\section{UK nuclear company funds broad study of genetic data}

Manchester. A plan to collect and analyse samples of genetic material from nearly every baby born in west Cumbria in the north of England over the next five years has been approved in principle by an ethics committee of the region's health authority.

John Burn and Louise Parker of the University of Newcastle upon Tyne have been guaranteed about $£ 300,000$ (US\$450,000), to cover at least the first three years of the project, by the Westlakes Research Institute, an independent organization set up outside Whitehaven, Cumbria, by British Nuclear Fuels (BNFL).

BNFL has struggled for a decade to shake off suspicion that its reprocessing plant at Sellafield in Cumbria might be responsible for a cluster of childhood leukaemia cases in the nearby town of Seascale. Last year, a High Court judge dismissed allegations that men exposed to radiation at the plant were more likely to father leukaemic children.

The company now hopes that it can allay lingering doubts with this new research and "prove there is no difference between the genetic make-up of children born to Sellafield fathers and those from the rest of the region", says a company spokesman.

Intended to involve 10,000 children, the project is likely to be the biggest single study so far in population genetics. It must now go through an extensive public consultation process to establish strict guidelines for handling an unprecedented mass of confidential genetic information. Barring delays, consenting parents could be providing samples of afterbirths early next year.

Burn says that BNFL's generous funding, which is far higher than its statutory requirements to monitor employees and the local environment for radiation exposure, is intended as both an effort to legitimize research sponsored by the nuclear industry and a lure to attract more scientists to the relatively isolated region.

To win preliminary assent from the West Cumbria Research Ethics Committee, Burn and Parker had to incorporate into their proposal a coding system to ensure the anonymity of donors. Before giving written and oral consent, prospective parents will see a video explaining how genetic information from their baby will be used.

Burn insists that he will consider using the code only when doing so will be of undisputed benefit to the child's health. $\mathrm{He}$ intends to put together an ethics committee, of nationally prominent geneticists and local people to decide what situations might merit such action. Its recommendations would have to be approved by the West Cumbrian committee, which Burn describes as "no pushover".

James Younger 